\title{
An Overview of the Principles of Jurisprudence Vis-A-Vis Legal Maxim
}

\author{
Mohammad Zaini Yahaya ${ }^{1}$, Muhammad Adib Samsudin ${ }^{1} \&$ Hayatullah Lalulddin ${ }^{1}$ \\ ${ }^{1}$ Shari'ah Department, Universiti Kebangsaan Malaysia, National University of Malaysia, Malaysia \\ Correspondence: Mohammad Zaini Yahaya, Shari'ah Department, Universiti Kebangsaan Malaysia, National \\ University of Malaysia, Malaysia. E-mail: zaiza@ukm.my
}

Received: August 20, 2013

doi:10.5539/ass.v10n2p157
Accepted: November 19, 2013 Online Published: December 29, 2013

URL: http://dx.doi.org/10.5539/ass.v10n2p157

\begin{abstract}
The Principles of Jurisprudence (Usul al-Fiqh) is a well-known science in the field of Shari'ah. Almost all institutions in Malaysia offering Islamic Studies in the field of Shari'ah make The Principles of Jurisprudence as compulsory course that must be taken by each candidate. This is due to the Principles of Jurisprudence dealing with crucial matters such as al-Dalil al-Ijmali (Comprehensive Proof), istinbat (derivation of rulings from nas (text) and debates related to ijtihad (the exertion of the utmost effort by a trained jurist). This study using both descriptive and analytical methods concludes that the Science of the Principles of Jurisprudence is extremely important for it equip the researcher with a clearer and deeper understanding of the Arabic speech rather than its linguistic sense and superficial meaning. Hence, the Principles of Jurisprudence is an absolute requirement for proper understanding of the Shari'ah, hence, derivation of rulings.
\end{abstract}

Keywords: Islamic jurisprudence, law, rulings principles, derivation, purposes of law and method

\section{Introduction}

In discussing the principles of jurisprudence scholars and writers, normally, begin with discussion of the individual component elements of the term separately, meaning to say principles, usul and fiqh, only then they attempt defining its collective meaning in a terminological sense. Due to the limit of space, this article will focus on elaboration of the meaning Principles of Jurisprudence on its own as an appellation of specific disciplines of Shari'ah related science.

Looking through the classic books one would not be able to find any specific definition for the usul al-fiqh. They contained only the meaning of its component elements usul and fiqh the former with the connotation of principle and the latter with jurisprudence. The reason for not defining the terms collectively as an appellation for specific sciences can probably be due its consideration by the classic scholars not as a separate scientific discipline of Islamic Jurisprudence. Therefore, we are obliged to refer to the books of contemporary or modern scholars in order to define the term usul al-fiqh collectively, in other words, to define it in terminological sense. Apparently, they seem not to have relied in their definition on any turath (classic) books except when defining the word usul (principles) and al-fiqh (jurisprudence) individually. Thus, it could be said that the definition of the usul al-fiqh in relative sense is the innovation of the contemporary scholars. From the definition of the contemporary scholars two definitions are selected and discussed as follow:

1) Al-Jilani Al-Mariniyy's Definition

Al-Jilani (2004) defines it as hukm kulliyy (universal ruling) based on which the periphery branches) of fiqh (jurisprudence) are constructed and which are expressed in general and concise phrases and independent of any specific situation.

\section{2) Ayman 'Abd Al-Hamid Al-Badarayn's Definition}

However, Ayman (2006) defines it as hukm kulliyy expressed in precise expressions by mean of which one is able to derive rulings from al-adillah (evidences) and to undertake reasoning, istidlal using certain methods, and to know the required conditions of the mustafid (jurist).

\section{Commentary on the Definitions}

The first definition is not comprehensive, because, some parts of fiqh ruling can be categorised as kulliyy 
(universal) too, for examples, the principle of al-darar yuzal (harm must be eliminated), contains a lot of furu' al-fiqh (branches of jurisprudence), expressed in general phrases and are not confined to any specific situation, and yet it is not considered as Principles of Jurisprudence.

The second definition is more precise and comprehensive, for it includes all related features of generality and avoids any features contrary to its comprehensiveness by not excluding any relevant subjects in the discussion of Principles of Jurisprudence which comprises of:

a) al-Dala'il

b) Istidlal

\section{c) Mujtahid}

These all subjects' matter of the science of Principles of Jurisprudence enjoys the privilege of parallel mention in the definition given in jurists' books. For example, al-Raziyy (1988) defined Principles of Jurisprudence as: Collection of the methods of Jurisprudence in general, legal reasoning and the required conditions of the jurist.

On the other hand, the contents of the definition given by Ayman al-Badarayn include mawdu' (subject) and the function of Principles of Jurisprudence. Inclusion of the mawdu' or subject matter in the definition is an indication of the scope of the coverage of the science of the Principles of Jurisprudence. It is important for further development of the principles and methods by researchers as far as they are within the boundary demarcated by the science of the Principles of the Jurisprudence. Meanwhile, the inclusion of the function (wazifah) in the definition portrays the established goals of the science of the Principles of Jurisprudence. Thus, the second definition is made the focal point of this paper.

\section{Relationship between Legal Maxims and the Principles of Jurisprudence}

Underscoring the existence of the relationship between the Islamic Legal maxims and the Principles of jurisprudence is not an easy task because the public consider the legal maxims as same as the Principles of Jurisprudence. Even some jurists hold both to be of the same nature. However, the existence of the Principles of Jurisprudence and al-qawa'id al-fiqhiyyah (Islamic Legal Maxims) is a contemporary need and requirement. Therefore, it is also required to establish a connection between scholars who know less about the Science of the Principles of Jurisprudence and those who are well versed in it. The existence of the Principles of Jurisprudence and Legal Maxims will make it easier for researchers to know the basic methods of istinbat, derivation of law, hence at least, enabling them to have an overview of the basics rules of Islamic Jurisprudence.

However, legal Maxims are more advanced than the Principles of Jurisprudence in terms of written works and discussion by the scholars. It is probable that a contemporary scholar could memorize dozens or even hundreds of Legal Maxim but if he is asked about the Principles of Jurisprudence he could hardly remember but a few such as al-amr li al-wujub (the command gives rise to an obligation), al-nahy li al-tahrim (forbidding gives rise to a prohibition) and al-asl fi al-ashya' al-ibahah (permissibility is the original state of things). Majority of the scholars know books like al-Ashbah wa al-Naza'ir (Similarities and Resemblances) or Qawa'id al-Ahkam (The Methods of the Rulings) while, having no idea about the book like Takhrij al-Furu' 'ala al-Usul (Deriving Branches from the Origin) and also al-Tamhid fi Takhrij al-Furu' 'ala al-Usul (Introduction to the "Deriving Branches from the Original Source"). This is the picture of the poor fate of the Principles of Jurisprudence in comparison to the well-known Legal Maxims.

Consequently, due to the existence of the wide gap between the two in terms of their reputation Ayman 'Abd al-Hamid al-Badarayn in his Ph.D thesis, Nazariyyat al-Taq'id al-Usuliyy, attempted to close the gap by highlighting the importance of the Principles of Jurisprudence and re-evaluating its foundations, history, and discussing its proposed topics. His thesis can be regarded as an important reference in the science of the Principles of Jurisprudence at the present time. His precise and concise discussion of the characteristics and conditions of Principles of Jurisprudence can be elaborated as follow:

1) The objective of the Principles of Jurisprudence is to ensure that the ijtihad (the exertion of the utmost effort by a trained jurist) move on the right direction, while the objective of the legal maxims is to control and guide the function and operation of the Principles of Jurisprudence itself.

2) Mawdu' (subject) of the Principles of Jurisprudence is al-dalil al-ijmali (general proof) while the subject of the legal maxim is the science of the Principles of Jurisprudence itself (al-Badarayn, 2006).

3) The Principles of Jurisprudence provide a general picture of the ruling (hukm) its dalil (evidence) and its nature. (Al-Badarayn, 2006). For example, in discussing mafhum al-mukhalafah (divergent meaning), it focuses on explaining the essence of mafhum al-mukhalafah, and its relevant argumentation and views offered by the 
scholars, whereas, in the legal maxim the main concern is the identification of legal status of an act or thing. For example, to say, mafhum al-mukhalafah hujjah, is accepted as a proof.

4) Using simple and concise expression. This characteristic is not the sole property of the science of Principles of Jurisprudence. Other disciplines too share this characteristic, as their principles also are formulated in simple expressions. (al-Badarayn, 2006) because, their expression in long sentences can be detrimental to the survival of the principle, for, simplicity of its expression facilitate its understanding, memorization hence, application.

These are some of the differences between the Principles of Jurisprudence and the Legal Maxims. In spite of their difference they cannot be separated from each other as in the same manner as Principles of Jurisprudence cannot be separated from the Jurisprudence al-Fiqh. However, due to the difference of subject matter and form they cannot be treated as one. This is asserted by Ayman al-Badarayn, however, he is not denying the previous view. Speaking objectively, what he did is acceptable and not contrary with some previous scholars who have written about the Principles of Jurisprudence partially in their work like al-Zinjaniyy in Takhrij al-Furu' 'ala al-Usul (Deriving Specific Cases From General Rules), al-Tilmisaniyy in Miftah al-Wusul fi Bina' al-Furu' 'ala al-Usul (The Key of Achievement in Developing The Branche based on the Origins) and al-Asnawi in al-Tamhid fi Takhrij al-Furu' 'ala al-Usul (Introduction To The "Deriving Specific Cases From General Rules"). Their writing method is identical with that of Qaedah al-Fiqh (Legal Maxim). They made Qaedah Usul al-Fiqh (Rule of Principles of Jurisprudence) as a discipline of its own, easy to understand, easy to remember and apply. It is presumed that the existence of Qaedah Usul al-Fiqh as a separate scientific discipline will give new impetus to the development of Usul al-Fiqh (Principles of Jurisprudence) by facilitating its better understanding and comprehension. On the other hand, assuming it as a form of innovation in Usul al-Fiqh it necessitates its being addressed by those involved in Usul al-Fiqh particularly and in Shari'ah generally. The presence of this knowledge will prove helpful in learning process as it will facilitate teaching in a more effective way. But to combine both in a single subject is not appropriate because Qaedah Usul al-Fiqh is just a complement to Usul al-Fiqh.

\section{Relationship between the Rule of the Principles of Jurisprudence and the Legal Maxim}

The difference between Qaedah Usul al-Figh and Qaedah al-Fiqh has been described by al-Qarafi (1998) in his book al-Furuq (Legal Differences), as he says:

Verily, the Shari'ah brought by Prophet Muhammad PBUH contains usul (principles) and furu' (branches). The usul has two parts. One of them called Usul al-Fiqh. Normally it is just principles that usually emerge from Arabic letters and utterances and the change that happen to them such nasakh (abrogation), tarjih (preference), and similar things pertaining their implication such as al-Amr li al-Wujub (Command Gives Rise to Obligation), al-Nahy li al-Tahrim (Forbiddeng Gives Rise to Prohibition), and also the connotation of particular expression and general meaning and so on. It also include principles that emerge based on the signification of the Arabic wordings and letters like qiyas (analogical deduction) as a hujah (proof), khabar ahad (singular narration) and mujtahid's (jurist) attitude. Second part: Qaedah al-Fiqh containing kulliyyat (universals) which include greatest, numerous, numbers of cases from varying fields and are much beneficial and contains the wisdom of Islam. Each principle contains uncounted number of furu', branches, of jurisprudence. No mention of wisdom behind ruling is made at all in Usul al-Fiqh even though inference is randomly provided in a generalized manner but not specifically and in detail.

From al-Qarafi statements mentioned above it is clear that he made some comparison between Qaedah Usul al-Fiqh and Qaedah al-Figh. This book as the main turath sources discusses the difference between Qaedah Usul al-Fiqh and Qaedah al-Fiqh. Other classic writings too discuses the difference between legal maxim and method of principles of jurisprudence, however, they elaborated on five or six basic differences which is hardly sufficient for providing a clear picture of their differences. However, Ayman 'Abd al-Hamid al-Badarayn by enumerating 14 differences between legal maxim and the method the principle of jurisprudence was able to provide a clear picture of the differences that exist between them pertaining the following aspects:

1) Aspects of Qat'iyyah (Certainty) and Zanniyyah (Speculation)

Most of the rules of Qaedah Usul al-Fiqh are qat'iyy (certain) implies certainty due to their being based on the evidence that are qat'I al-dalalah (definitive in meaning) while, most of Qawaed al-Fiqh are speculative in nature and their implications are speculative, for they are open to certain exception (al-Badarayn, 2006).

\section{2) Aspect of Numbers}

Qawaed al-Fiqh, as al- Qarafi (1998) holds, are numerous. This is so because they are established through research on various furu' from different areas of Islamic jurisprudence and which are united under one rule. 
There is a large number of qawaed al-fiqh which are contained in both types of books, classic and modern. Al-Burnu, for example, discussed 4192 legal maxims in Mawsu'ah al-Qawa'id al-Fiqhiyyah (The Encyclopaedia of Legal Maxims) (al-Badarayn, 2006). Whereas, the case is different with the Qaeda Usul al-Fiqh for they are not developed in the light of reference to the furu' of Islamic jurisprudence except among the early scholars like Hanafi.

3) Aspect of Consensus and Contradiction

Qaedah Usul al-Fiqh generally, is not prone to any contradiction, whereas, Qaedah al-Fiqh often faces certain contradiction in various areas of Islamic jurisprudence. This presents a stark difference between the method of the principles of jurisprudence and that of legal maxim (al-Badarayn, 2006).

4) Aspect of Subject

Subject matter of Qaedah Usul al-Fiqh is Usul al-Fiqh while subject matter of Qaedah al-Figh is furu' of jurisprudence that can be brought under one unified ruling based on their similarities (al-Burnu, 1997).

5) Aspect of Relation with Arabic Language, Akidah (Faith) and Mantiq (Logic)

We cannot distinguish the Qaeda Usul al-Figh from the principles of Arabic Language, principle of Akidah (faith) and principle of Mantiq (Logic) if its principles are derived from theses sources. (Al-Badarayn, 2006). For example:

أقل الجمع ثلاثة

Meaning: Minimum of $J_{a m a}$ (plural) is three.

This principle constitute a Qaedah of Usul al-Fiqh and at the same time it is a principle of Arabic Language.

6) Aspect of Scientific Advantage Based on Furu'

Qaedah Usul al-Fiqh is used more often. For, every single juristic rule must have connection with Qaedah Usul al-Fiqh either in respect of istinbat or ta'arud (contradiction) or tarjih (preference). Thus, every ijtihad must undergo the successful test of compliance with the Qaedah Usul al-Fiqh. Unlike this, Qaedah al-Figh is not subject to this requirement due to multiplicity of its furu', which cannot be included within the scope of its application. Nevertheless, many furu' (branches) do not require Qaedah al-Fiqh for attaining their relevant rulings (al-Badarayn, 2006).

7) Aspect of Motive

Although both, the rule of the principles of Islamic jurisprudence and legal maxim have the same common goal of operationalization of ijtihad and its control but in respect of their specific objectives and motives they differ from each other. Qaedah Usul al-Fiqh controls ijtihad in terms of generalized evidence of how to conduct istinbat and the conditions of mujtahid. Thus, Qaedah Usul al-Fiqh provides methods of interpretation of nas (text), conditions for the use of evidence not based on nas (text). On the contrary, Qaedah al-Fiqh is concerned mainly with the provision of rulings to the furu' that come under its scope and implication (al-Badarayn, 2006).

\section{8) Aspect of Existence}

Theoretically, Qaedah Usul al-Fiqh emerged earlier than Qaedah al-Fiqh whereas; Qaedah al-Fiqh emerged after the accumulation of numerous juristic furu'. Usul al-Fiqh functions as a mean of istinbat. Therefore, it is logical to presume its existence prior to the existence of the furu'. This is because of the impossibility of ijtihad hence, the existence of the corpus of the juristic law without the existence of the Qaedah Usul al-Fiqh (al-Badarayn, 2006).

9) Aspect of Authority and Strength

Generally, the authority of Qaedah Usul al-Fiqh is accepted with certainty due to to its definitive implication. On the other hand, Qaedah al-Figh lacks such implication for; its acceptance is not unanimously agreed upon between scholars. Nevertheless, some scholars regard Qaedah al-Fiqh as a supportive evidence of ijtihad only. This is so in the case of those who fulfill all the conditions and are fully aware of all cases that can be exempted. However, those admitting Qaedah al-Fiqh as authority in ijtihad do not allow it in all cases but only in certain cases (al-Zarqa, 1988).

10) Aspect of Foundation

Mostly, the basis of Qaedah of Usul al-Fiqh can be traced to the semantic rules and regulations of Arabic Language especially in respect of interaction with nusus (texts) as al-Qarafiyy (1998) has stated. On the contrary, Qaedah al-Fiqh, legal maxim is constructed through the process of induction of the existing furu' of 
jurisprudence (al-Badarayn, 2006).

\section{1) Aspect of the Authority of Maqasid al-Shari'ah (Objectives of Islamic Law)}

Ayman 'Abd al-Hamid al-Badarayn rejects the view which assert the impossibility of understanding of the wisdom of Islamic law through Qaedah Usul al-Fiqh's. He politely rejects this view by saying that there are some Qaedah Usul al-Figh's that have Maqasid al-Shari'ah in sight. For instance, qiyas (analogical deduction), has it in sight especially in relation to the discussion of al-'Illah al-Mu'aththirah (Effective Cause), al-Masalih al-Mursalah (Unrestricted Interest), Sadd al-Dhara'i (Blocking the Means), al-Istishab (Presumption of Continuity), al-Istihsan (Juristic Preference/Equity) and others methods have the Maqasid al-Shari'ah in insight during their operationalization (al-Badarayn, 2006).

Evidently, from our point of view, the difference of opinions pertaining this issue is due to the question of whether Maqasid al-Shari'ah is part of Usul al-Figh or as a separate discipline in its own right? For those who consider it as a part of Usul al-Fiqh, there is no issue here. But for those who consider Maqasid al-Shari'ah as a separate scientific discipline, Usul al-Fiqh does not discuss Maqasid al-Shari'ah. Therefore, the arguments presented by Ayman 'Abd al-Hamid al-Badarayn could not shake their stand for, all the examples given above could not clearly reveal the Maqasid al-Shari'ah unless in very difficult way. In fact, what Ayman al-Badarayn presented is what Ibn 'Ashur has stated in his book, Maqasid al-Shari'ah al-Islamiyyah (Ibn Ashur, 2001):

On the other hand, there is some underlying secret in some issues of Usul al-Fiqh in various chapters which are not investigated property and are abandoned -during research- in the book of Usul al-Figh. Discovery of these secretes or underlying meanings are of such a nature that the authors would not easily comprehend unless they are endowed with a strong sense of patience and endurance. Due to this reason these secret meanings which are more appropriate to be classified as al-Maqasid are considered unimportant and are not given a proper attention. Those issues comprises debate pertaining al-Munasabah (Appropriateness), al-Ikhalah (Appearance of Goodness) in Masalik al-'Illah (methods of the discovery of the cause), al-Masalih al-Mursalah, al-Tawatur (Recurrence), and etc.

Apparently, some researchers with no inclination of separating Usul al-Fiqh from Maqsid al-Shari'ah have obviously made some efforts to integrate Usul al-Fiqh and Maqasid al-Shari'ah. Some even indulged themselves with polemics revolving around debates pertaining Maqasid al-Shari'ah in various scientific books including Usul al-Fiqh written by scholars in 4thHejira. Some of the books are al-al-'Ilal (the Causes) or Ithbat al-'Ilal (Substantiation of the Causes") by Abu 'Abd Allah Muhammad bin 'Ali al-Tirmidhiyy (al-Hakim) who died in 320Hejira, Mahasin al-Shari'ah (The Virtues of the Shari'ah) by Abu Bakr al-Qaffal al-Shashiyy who died in 364 Hijrah, book of al-'Ilam bi Manaqib al-Islam (An Exposition of the Virtues of Islam) by Abu al-Hasan al-'Amiriyy and of course al-Burhan fi Usul al-Fiqh (the Authority in the Principles of Jurisprudence)) by Abu al-Ma'ali Imam al-Haramayn al-Juwayniyy who died in 478Hijrah. Even Imam al-Haramayn is the first who divide al- Masalih al-Mursalah into three categories; al-Daruriyyat (Essentials), al-Hajiyyat (Necessaries) and al-Tahsiniyyat (Embellishments) under chapter Taqasim al-'Ilal wa al- Usul (Divisions of Cause and Principles) in the book of al-Qiyas (The Analogical Method of Derivation) from al-Burhan fi Usul al-Fiqh (Book of Demonstration on Jurisprudence) (al-Juwainiyy, 1997).

12) Aspects of Generalization and Consistence

The rule of Usul al-Figh is more consistent in comparison to Qaedah al-Fiqh for, the later has many exceptions due to which it has been identified with the character of aghlabiyyah (general) (al-Zuhaili, 2006). This led some scholars to take initiative in producing books covering all examples that could be exempted from Qaedah al-Fiqh such as al-Munaqadat fi al-Hasr wa al-Istithna' (Contradiction on The Cramming and The Exclusion) by Ahmad bin al-Husayn al-Fannakiyy and al-Istighna' fi al-Farq wa al-Istithna' (Dispensing on The Different and The Exclusion) by Badr al-Din Muhammad al-Bakriyy al-Shafi'iyy (al-Bahisin, 1998).

13) Aspects of Usul and Furu'

Knowledge of Qaedah Usul al-Fiqh is a necessary condition of ijtihad through which the existence of juristic furu' is realised), on the other hand, Qaedah al-Fiqh is constructed based on the juristic furu'. Therefore, Qaedah Usul al-Fiqh is the origin of the juristic furu' (al-Badarayn, 2006).

14) Aspect of the Method of Construction of Juristic Furu'

The rule of Usul al-Figh is something which is strictly followed by mujtahid in the process of istinbat. On the other hand, Qaedah al-Figh is a collection of various cases under one ruling due to their similarity and resemblance (al-Badarayn, 2006). 
Although there are many differences between the rule of Usul al-Fiqh and Qaedah al-Fiqh they also have some principles in common. This partnership can be seen from different aspects. If we were to consider it from the aspect of it generality and its being as an evidence through which istinbat, derivation of ruling is facilitated then it resemble to Qaedah Usul al-Fiqh. However, considering it from the aspect of its being as a specific evidence establishing a legal obligation for mukallaf (subject of law) it resemble to Qaedah al-Fiqh (al-Burnu, 19970). For example, Sadd al-Dhara'i (Blocking the Means) if we consider it from the aspect of its generality as a general evidence for the derivation of ruling, which is " the proof of establishing the prohibition of something is also the proof of the prohibition of what lead to the establishment of the prohibited thing.", then it is considered as Qaedah al-Fiqh. Instead, if consider it from the aspect of its being a specific ruling imposed on the subject of the law than we can conclude that "everything mubah (permissible) if lead into illegal it is forbidden" then in this sense it is considered as Qaedah al-Fiqh.

\section{Main Reference of the Rule of Usul Al-Fiqh}

Generally, all books of Usul al-Fiqh regardless of their being in the form of matan (the text) or sharh mukhtasar (abridgement) or hashiyah (marginal notes) constitute the essential references for Rule of Usul al-Fiqh. However, some of these books having their own style have discussed subjects pertaining to Usul al-Fiqh more elaborately in the form of principles than others.

\subsection{Turath Books}

Turath books constitute the primary sources for the study of Usul al-Fiqh. Some of these books involve directly in the discussion of Qaedah al-Fiqh such as:

i. Al-Qawa'id wa al-Fawa'id al-Usuliyyah wa Ma Yata'allaq biha min al-Ahkam al-Far'iyyah (Principles and Advantages of Principles of Jurisprudence and Their Related Juristic Rulings) by 'Ali bin Muhammad bin 'Abbas bin Shayban al-Ba'liyy or well-known as Ibn al-Lahham al-Hanbaliyy.

ii. Al-Wusul ila Qawa'id al-Usul (Comprehension of the Principles of Fundamentals) by Muhammad bin Abdullah bin Ahmad al-Tamartashiyy al-Ghazziyy al-Hanafiyy.

Among the classic juristic books that discuss directly Qaedah Usul al-Figh including their juristic application and are classified as takhrij al-furu' 'ala al-usul (Exposition of the Peripheries from the Roots) based on Qaeda Usul al-Fiqh for example:

a) Takhrij al-Furu' 'ala al-Usul (Exposition of the Peripheries Based on The Principles) by Mahmud bin Ahmad bin Mahmud al-Zinjaniyy al-Shafi'iyy.

b) Miftah al-Wusul fi Bina' al-Furu' 'ala al-Usul (The Key of Arriving at the Construction of Branchs Based on Roots) by Muhammad bin Ahmad bin Yahya bin 'Ali al-Tilmisaniyy al-Malikiyy.

c) Al-Tamhid fi Takhrij al-Furu' 'ala al-Usul (Introduction to Derivation of Specific Cases From General Rules) by 'Abd al-Rahim bin al-Hasan al-Asnawiyy.

\subsection{Modern Books}

Some of the modern books discuss Qaedah Usul al-Fiqh in particular way. This sort of books can be classified into two types:

i. General books of Qaedah Usul al-Fiqh such as:

a) Athar al-Ikhtilaf fi al-Qawa'id al-Usuliyyah fi Ikhtilaf al-Fuqaha' (The Effect of Difference in The Principles of Jurisprudence on Difference of Jurists Opinions), Ph.D Thesis by Mustafa Sa'id al-Khinn.

b) Al-Qawa'id al-Usuliyyah al-Muta'alliqah bi Fiqh al-Mu'amalat: Dirasah Usuliyyah Fiqhiyyah Muqaranah, (Juristic Principles Pertaining Transactional Jurisprudence) A Juristic Comparative Study), Ph.D Thesis by Dusuqi Yusuf Dusuqi.

c) Al-Qawa'id al-Mushtarakah Bayn Usul al-Fiqh wa al-Qawa'id al-Fiqhiyyah (The Shared Principles Between Principles of Jurisprudence and Legal Maxims), Ph.D Thesis by Sulayman bin Salim Allah Raja' al-Rahiliyy.

d) Nazariyyat al-Taq'id al-Usuliyy (The Theories Juristic Engagementof), Ph.D Thesis by Ayman 'Abd al-Hamid al-Badarayn.

ii. Scriptures pertaining the study of Qaeda Usul al-Fiqh in particular books such as

a) Al-Qawa'id al-Fiqhiyyah wa Tatbiqatuha al-Fiqhiyyah 'ind Ibn Qudamah fi Kitabih al-Mughni (The Rules of the Principles of Jurisprudence and its Juristic Application according to Ibn Qudamah in his book The Sufficient), Ph.D Thesis by al-Jilali al-Mariniyy. 
b) Al-Qawa'id al-Usuliyyah 'inda al-Imam al-Shatibiyy min Khilal Kitabih al-Muwafaqat (The Rules of the Principle of Jurisprudence According to al-Imam al-Syatibiyy in his Book Agreements on the First Principles of Islamic Law), Master Thesis by al-Jilali al-Mariniyy.

c) al-Qawa'id al-Muta'alliqah bi al-Qiyas wa al-tatbiq 'Alayha min Kitab Fath al-Bari li Ibn Hajar (The Rules Pertaining Analogy and Their Application in The Book of "The Creator's Conquest") by Ibn Hajar, Thesis by Sa'di 'Ali al-Haddad.

\section{Application of the Rule of Principles of Jurisprudence}

As noted earlier, every ijtihad must go through Qaedah Usul al-Fiqh. However, this is not the case with the fiqh (jurisprudence) due to its goals being specifically confined to the statement of the laws and their sources briefly. The application of the Qaedah Usul al-Figh, can easily be observed in books classified as Takhrij al-Furu' 'ala al- Usul (Deriving Specific Cases from General Rules). And other related books. To present the examples, we will divide the discussion into two sections in respect of derivation of law from al-Quran and al-Sunnah (Prophetic Tradition).

\subsection{Examples of the Application of the Rule of the Principles of Jurisprudence for the Derivation of the Ruling from Al-Quran}

Allah says in al-Quran:

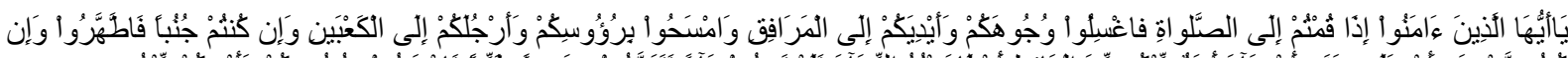

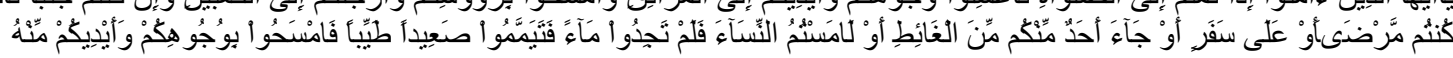

Meaning: $\mathrm{O}$ ye who believe! When ye prepare for prayer, wash your faces, and your hands (and arms) to the elbows; Rub your heads (with water); and (wash) your feet to the ankles. If ye are in a state of ceremonial impurity, bathe your whole body. But if ye are ill, or on a journey, or one of you cometh from offices of nature, or ye have been in contact with women, and ye find no water, then take for yourselves clean sand or earth, and rub therewith your faces and hands.

Among the Rules of the Principles of Jurisprudence through which the verse can be understood is:

i. حرف الواو للترتيب

Meaning: The letter (و) connotes sequence or order.

In the above verse pertaining the act of ablution the letter (و) is used as a conjunction.'ataf (coupling) letter. Thus, based on the rule of Usul al-Fiqh, we understand that the act of ablution as described in the verse is washing face, both hands till elbows, touching one's head and washing feet up to ankles must be done in tartib in sequence and order) (al-Zinjani, 1987).

ii. إذا دار اللفظ بين الحقيقة والمجاز جاز أن يكون كلاهما مر ادا (a)Z

Meaning: when a word revolves around metaphorical and real meanings both can be presumed to be the desired meaning.

In the verse above, expression (أو لامستم النساء) has two meanings, al-Haqiqi (real meaning) and Majazi (metaphoric meaning). The real meaning is to touch and the metaphorical meaning is to have intercourse. According to the principle, this verse gives the meaning that a person touching a woman to whom he can legally marry will nullify his ablution because it, Real meaning) is one of the two desired meanings, which is held by scholars of Shafi'i sect, but Hanafi scholars chose the metaphorical meaning in this situation based on the consideration of other arguments. (Al-Zinjani, 1987).

iii. مطلق الأمر يقتضي التكرار

Meaning: Absolute command requires repetition.

Based on this rule, Shafi'i scholars understood the amr (command) of ablution for prayer to be requiring repetitiveness. In other word, a person cannot do tayammum (ablution performed with sand instead of water) to perform obligatory prayers except during praying time. This is because the meaning of amr (command) requires repetition (al-Zinjani, 1987).

\subsection{Application of the Rule of the Principles of Jurisprudence in Derivation of the Ruling from Al-Sunnah} (Prophetic Tradition)

Al-Tirmidhiyy narrated from al-Walid ibn Muslim from Mu'awiya ibn Yahya al-Sadafiyy from al-Zuhriyy from Abu Hurayrah from the Prophet Muhammad words:

لا يؤذن إلا منوضئ 
Meaning: a person without ablution cannot conduct the call for prayer.

The application of this rule can be viewed from two aspects.

\section{Firstly: From the Aspect of the Strength of the Hadith}

Considering the chain of the narration of the hadith there are narrators who have been dropped from the chain of the narrators of the hadith.(Al-Qattan, 1987, p. 1090) It is clear from the fact that al-Zuhriyy, as one of the narrators in the chain did not narrate hadith (prophetic tradition) from Abu Hurairah, therefore based on rule the Usul al-Fiqh the hadith with missing connection in the chain of its narration is not considered as a an evidence for the establishment of a ruling.

لا تقوم الحجة بالحديث المنقطع

Meaning: A narration with a missing connection in its chain of narrator is not a sufficient proof.

Thus, this hadith cannot be used as evidence to say that azan (call to prayer) without ablution is not acceptable.

\section{Secondly: From the Aspect of its Derived Ruling}

The proponents of this hadith claimed that even though this hadith is expressed in the form of ayat khabariyyah (enunciative) statement, it intent is constructive insha'iyyah hence, implies prohibition. It is a rule of Usul al-Fiqh that:

النهي للتحريم

Meaning: Prohibition give rise to forbidding.

Therefore, this rule implies that to perform the call for prayer without ablution is prohibited and this prohibition includes all types of azans, such as azan for five times prayer, azan of Friday prayer azan of traveller etc. based on the rule of the, generality of the implication of the indefinite noun in the context of negation.

النفي تعم النكرة في سياق

The opponents of this hadith argued based on a hadith sahih (authentic tradition) in which it is mentioned that al-Muhajir bin Qunfudh met the Prophet Muhammad who was urinating. Al-Muhajir gave salam (greeting), but he did not answer until he performing wudhuk (ablution). Then he said as narrated by Abu Dawud:

إني كرهت أن أذكر الله إلا على طهر أو قال على طهارة

Meaning: I don't like to praise of Allah unless I am free from hadath (excrement).

They state that the practice of the prophet is sunnah and it is expressed as an explicit cause which is zikrullah, remembrance of Allah. It is the rule of the Principles of Jurisprudence, that the cause covers all its related cases.

العلة تعمم معلولها

From this rule of the Principles of Jurisprudence it can be concluded that, in all forms of zikrullah (remembrance of Allah) it is mandub (recommended) to have ablution including azan.

Apart from the application of rule of Usul al-Fiqh in al-Quran and al-Sunnah (Prophetic Tradition), it can be applied also in all subject of the Science of the Usul al-Fiqh. Thus, the examples mentioned are meant to provide a brief description of the forms of the application of rule of the Principles of Jurisprudence, in derivation of ruling from al-Quran and al-Sunnah.

\section{Conclusion}

The significance of the rules of Science of Usul al-Figh (Principles of Jurisprudence) is crystal clear from the forgoing discussion. However, despite its significance, it lacks adequate attention unlike Qaedah al-Fiqh. This can be attributed to its being as branch of knowledge in its own right, having its own function and ability of self-propelled development, which is not known to many researchers. Theoretically, the Science of the Principles of Jurisprudence is as much needed branch of Science as the Science of Legal Maxims. Therefore, concerted efforts should be made to expose the rules of the Science of the Principle of Jurisprudence and compile then in specific book in the form of collection of the Rules of the Science of the Principles of Jurisprudence. Well organized and continuous effort in this direction will bear fruit and lead to the production of books of the Rules of the Principles of Jurisprudence in the same form as that of the books pertaining Legal Maxims with their related cases and application. To achieve this three steps are needed to be taken which comprises, rewriting of all the existing rules of the Principles of Jurisprudence in a separate book, hence coordinating and organizing them in the light of the difference of scholars. Then reconstructing them in the concise and precise phrases, hence, establishing the relationship between these rules and their application as mentioned in the classic books of the Principles of Jurisprudence. Hopefully this suggestion will attract the attention of the researchers especially in the field of the Principles of Jurisprudence, hence instigating further research in this respect 


\section{References}

Al-'Amidiyy, Al-Din, S., Ali, A. B. A., \& Al-Ahkam, A. F. U. (Exactitude in the Sources of Legal Judgments). Beirut: Darul Kutub al-'Ilmiyyah (Publishing House of Scientific Books).

Al-Badarayn, A. A. A. (2006). Nazariyyat al-Taq'id al-Usuliyy. Beirut: Dar Ibn Hazm.

Al-Bahisin, Y. B. A. A. (1998). Al-Furuq al-Fiqhiyyah wa al-Usuliyyah. Riyadh: Maktabat al-Rushd.

Al-Burnu, \& Ahmad, M. S. B. (1997). Mawsu'ah al-Qawa'id al-Fiqhiyyah (The Principles of Jurisprudence Encyclopedia). Riyadh: Maktabat al-Tawbah (al-Tawbah's Bookstore).

Al-Jassas, \& Al-Raziyy, A. B. A. (1405 Hijrah). Ahkam al-Quran (Rulings of the Qur'an). Inquisitor: Muhammad al-Sadiq Qamhawiyy. Beirut: Dar Ihya' al-Turath al-'Arabiyyah Publishing House of Arabic Classic Books).

Al-Jilali, \& Al-Mariniyy. (1423 Hijrah/2001 A.D.). Al-Qawa'id al-Fiqhiyyah wa Tatbiqatuha al-Fiqhiyyah 'ind Ibn Qudamah fi Kitabih al-Mughni (Principles of Jurisprudence and Implementations by Ibn Qudamah in his book "The Sufficient"). Saudi Arabia: Dar Ibn al-Qayyim (Publishing House of Ibn Qayyim).

Al-Jilali, \& Al-Mariniyy. (1425 Hijrah/2004 A.D.). Al-Qawa'id al-Usuliyyah 'inda al-Imam al-Shatibiyy min Khilal Kitabih al-Muwafaqat (The Juristic Rules by al-Imam al-Syatibiyy based on his book "Agreements On The First Principles of Islamic Law") Saudi Arabia: Dar Ibn al-Qayyim (Publishing House of Ibn al-Qayyim).

Al-Juwayniyy, \& Yusuf, I. A. A. A. B. A. A. B. (1997). Al-Burhan fi Usul al-Fiqh (Book of Demonstration on Jurisprudence). Inquisitor: 'Abd al-'Azim Mahmud al-Dib. Mansoura: Dar al-Wafa' (Publishing House of Loyalty).

Al-Qarafiyy, \& Idris, S. A. A. B. (1998). Al-Furuq (Legal Differences). Checked and corrected by Khalil al-Mansur. Beirut: Dar al-Kutub al-'Ilmiyyah (Publishing House of Scientific Books).

Al-Qattan, M. (1987). Mabahith fi 'Ulum al- Hadith. Cairo: Maktabat Wahbah.

Al-Rahman, J. A. A. (1990). Ghayat al-Wusul ila Daqa'iq 'Ilm al-Usul, al-Mabadi' wa al-Muqaddimat. Egypt: Matba'at al-Jabalawiyy.

Al-Raysuniyy, Ahmad, Al-Maqasidiyy, I. A., \& Al-Juwayniyy, A. A. I. A. (Anniversary of Imam al-Haramyn al-Juwayniyy.) (1999, April 6-8). University of Qatar.

Al-Raziyy, \& Umar, F. A. M. I. (1988). Al-Mahsul fi Usul al-Fiqh (The Substance in The Foundations of Jurisprudence). Beirut: Dar al-Kutub al-'Ilmiyyah (Publishing House of Scientific Books).

Al-San'aniyy, \& Al-Yamaniyy, M. B. I. A. (1988). Subul al-Salam sharh Bulugh al-Maram ("Paths of the Peacefulness", commentary on "Attainment of the Objective"). Inquisitor: Muhammad 'Abd al-Qadir Ahmad 'Ata. Beirut: Dar al-Kutub al-'Ilmiyyah (Publishing House of Scientific Books).

Al-Subkiyy, Al-Kafi, S. A. A. I. A., \& Ali, I. A. T. A. A. A. I. (1404Hejira/1984A.D.). Al-Ibhaj fi Sharh al-Minhaj ("The Gladdening": An Exegesis of "The Road"). Mecca: Dar al-Baz (Publishing House of al-Baz).

Al-Tirmidhiyy, Isa, A. I. M. B., \& Al-Sahih, A. (A Collection of The Prophet's Authentic Traditions) (n. d.). Inquisitor: Muhammad Shakir. Beirut: Dar Ihya' al-Turath al-'Arabiyy (Publishing House of Restoration Arabic Classic).

Al-Zarqa. (1998). Mustafa Ahmad al-Madkhal al-Fiqhiyy al-'Am. Damscus: Dar al-Qalam.

Al-Zinjaniyy, \& Ahmad, S. A. M. B. (1987). Takhrij al-Furu' 'ala al-Usul. Inquisitor: Muhammad Adib Salih. Beirut: Mu'assasat al-Risalah.

Al-Zuhayliyy, \& Mustafa, M. (2006). Al-Qwa'id al-Fiqhiyyah wa Tatbiqatuha fi al-Madhahib al-Arba'ah. Damascus: Dar al-Fikr.

Ashur, I., \& Al-Tahir, M. (2001). Maqasid al-Shari'ah al-Islamiyyah. Inquisitor: Muhammad al-Tahir al-Misawiyy. Jordan: Dar al-Nafa'is.

Dawud, A., Al-Ash'ath, S. B., \& Dawud, S. A. (Collected by A. Daawood) (n. d.). Inquisitor: Muhammad Muhyi al-Din 'Abd al-Hamid. Beirut: Dar al-Fikr (Publishing House of Thought).

Fulusi, M. B. M. (2004). Mudarasat al-Mutakallimin wa manhajuha fi dirasat usul al-fiqh . Arab Saudi. Maktabat al-Rushd. Retrieved from http://www.mmf-4.com/vb/t2727.html

Hajar, I., \& Hajar, A. B. A. B. (1989). Fath al-Bari Sharh Sahih al-Bukhariyy. Inquisitor: 'Abd 'Aziz bin Baz. Beirut: Dar al-Kutub al-'Ilmiyyah.

\section{Copyrights}

Copyright for this article is retained by the author(s), with first publication rights granted to the journal.

This is an open-access article distributed under the terms and conditions of the Creative Commons Attribution license (http://creativecommons.org/licenses/by/3.0/). 